\title{
Comparison of Dissolution Profiles and Apparent Permeabilities of Commercially Available Metformin Hydrochloride Tablets in Turkey
}

Yagmur Akdag, Tugba Gulsun, Nihan Izat, Levent Oner, and Selma Sahin*
All authors: Department of Pharmaceutical Technology, Faculty of Pharmacy, Hacettepe University, Ankara, Turkey.

e-mail: sahin.selma@gmail.com

\section{ABSTRACT}

The purpose of this study was to evaluate the similarity of dissolution and permeability properties of commercially available immediate-release metformin hydrochloride $(\mathrm{MH})$ tablets (1000 $\mathrm{mg}$ strength) including five generic products obtained from the Turkish drug market (tablets $A-E$ ) and two reference products (obtained from the Turkish and European markets). In vitro dissolution studies were conducted in accordance with the $\mathrm{MH}$ tablet monograph in the USP (1000 mL, $75 \mathrm{rpm}$ ) and with the BCS-based biowaiver guidance in three different media $(\mathrm{pH} \mathrm{1.2,} \mathrm{pH} 4.5$, and $\mathrm{pH}$ 6.8; $900 \mathrm{~mL}, 50 \mathrm{rpm}$ ). The apparent permeability of $\mathrm{MH}$ in all tablets and raw $\mathrm{MH}$ was determined in Caco-2 cells. Dissolution studies revealed that neither the generics (except generic tablet B) nor the reference tablets fulfilled the criteria for very rapid dissolution. Although the dissolution profiles of the reference tablets were similar $\left(f_{2}>50\right)$, none of the generic tablets were similar to either of the reference tablets. Permeability of $\mathrm{MH}$ for all reference and generic tablet formulations was similar to that of raw $\mathrm{MH}(p>0.05)$. In contrast, a significant difference in permeability was observed between the two reference tablets $(p<0.05)$, and only one generic tablet $(A)$ had permeability similar to both reference tablets. As $\mathrm{MH}$ has low permeability, potential alterations in permeability due to the dosage form can affect its bioavailability. The results of this study indicate that immediate-release $\mathrm{MH}$ tablets do not meet the criteria for very rapid dissolution for the BCS-based biowaiver.

KEYWORDS: Metformin hydrochloride, dissolution profile, biowaiver, permeability

\section{INTRODUCTION}

$\mathrm{M}$ etformin hydrochloride $(\mathrm{MH})$ is a biguanide antidiabetic agent used for the treatment of type 2 diabetes mellitus $(1,2)$. It is the most frequently used oral antidiabetic agent, used by approximately 150 million patients per year worldwide in the last 60 years. $\mathrm{MH}$ is safe and effective (3), and is recommended as the first-line medication by the American Diabetes Association and European Association for the Study of Diabetes (4). The reference MH tablets for standard care are available in the market in three strengths (500, 850, and $1000 \mathrm{mg}$ ) (5). In addition to the reference $\mathrm{MH}$ tablets, six generic formulations of the same strengths are commercially available in the Turkish Drug Market.

According to the European Medicines Agency (EMA), United States Food and Drug Administration (FDA), and World Health Organization (WHO) guidelines, immediate-release (IR) $\mathrm{MH}$-containing tablets are subject to a BCS-based biowaiver because $\mathrm{MH}$ drug substance is a BCS Class 3 drug (6-10). The criteria for the BCS-based biowaiver recommended by EMA and FDA are as follows: high solubility and limited absorption for drug substance; very rapid in vitro dissolution rate for test and reference drug products; and no change in excipients that might affect bioavailability $(7,8)$.

Two main parameters govern the oral absorption of compounds, namely the dissolution from the dosage form and permeability across the gastrointestinal tract. For BCS Class 1 compounds, neither dissolution nor permeability are expected to limit the absorption as the compounds have high solubility and high permeability. In contrast, the rate-limiting step in absorption is dissolution for Class 2 compounds and permeability for Class 3 compounds. According to the EMA, "a generic medicinal product is a product which has the same qualitative

*Corresponding author

Dissolution|

Technologies FEBRUARY 2020

www.dissolutiontech.com 
and quantitative composition in active substances and the same pharmaceutical form as the reference medicinal product, and whose bioequivalence with the reference medicinal product has been demonstrated by appropriate bioavailability studies" (7). Therefore, a BCSbased biowaiver may be applicable for IR products of Class 1 and 3 compounds if all recommended conditions are met $(7,8)$.

The dissolution test is an important tool in drug development and quality control studies for tablet formulations. It is also used to design new formulations, develop in vitro-in vivo correlations, control in-process and finished product specifications, show the similarity of pharmaceutical dosage forms, and evaluate the bioequivalence of reference and generic products (11, 12). Permeability is the rate-limiting step in the oral absorption of BCS Class 3 compounds such as MH (13). The permeability of a drug substance can be investigated by in vitro methods (monolayers of suitable epithelial cells and excised intestinal tissues), in situ, through in vivo intestinal perfusion in a suitable animal model, and in vivo in human studies (absolute bioavailability and mass balance studies) (8). The Caco-2 monolayer cell model is used widely as an in vitro method to study the transport of soluble drugs. However, owing to the absence of $\mathrm{M}$ cells, the uptake studies of particles are not possible. Therefore, various co-culture models have been established to emphasize the human intestine with $\mathrm{M}$-cell like morphology. Kerneís et al. developed co-cultures of Caco-2 cells and Peyer's patch lymphocytes in which the murine lymphocytes were replaced with the human B-cell line Raji. Gullberg et al. also established physically separated co-cultures of human Raji B-and Caco-2 cells as a simpler phenotypic model to be used for oral drug delivery systems, such as oral vaccine delivery (14-16).

Among these methods, permeability across Caco-2 cells is a useful in vitro tool for investigating the apparent permeability of active ingredients and the potential effects of excipients on their permeability. The Caco2 monolayer shows higher transepithelial electrical resistance (TEER) values than another human colon adenocarcinoma cell line HT29; thus, it provides a better simulation of in vivo conditions (17). Caco-2 cells express transporters, enzymes (e.g., esterase), and receptors that are expressed in the epithelium (18); however, because of a potentially low (or absent) expression of efflux and uptake transporters, its use in BCS classification is limited to passively absorbed drugs. Although there is no mucus and unstirred water layer in Caco-2 cells, a good correlation was observed between Caco-2 and the jejunum with regard to passive drug absorption (19-21). In 2018, the draft ICH guideline M9, on Biopharmaceutics Classification System-based biowaivers (step 2), revealed a validated and standardized in vitro permeability assessment method in Caco-2 cells (22). Some regulatory authorities (e.g., South Korea, USA) accept Caco-2 cell data as primary evidence of permeability; others (e.g., Australia, Canada, EU, New Zealand, WHO) consider it as supporting data (23).

The purpose of this study was to investigate the similarity of five generic $\mathrm{MH}$ tablets (1000 mg strength) available in the Turkish drug market to the reference $\mathrm{MH}$ tablets obtained from Turkish and European Markets through an evaluation of their dissolution and permeability. Dissolution studies were performed in accordance with the $\mathrm{MH}$ tablet monograph in the USP and the BCS-based biowaiver guidance in three different medium conditions (pH 1.2, pH 4.5, and pH 6.8). Permeability studies across the Caco-2 cell monolayer were conducted to determine the permeability of raw $\mathrm{MH}$ and $\mathrm{MH}$ in commercial tablets.

\section{MATERIALS AND METHODS \\ Materials}

$\mathrm{MH}$ was kindly provided by Sanovel Pharmaceuticals, Turkey. HPLC-grade acetonitrile was obtained from Sigma-Aldrich. Water was purified by using a Milli-Q system (MilliporeUSA). Potassium chloride ( $\geq 99.0 \%$; Sigma-Aldrich, USA), hydrochloric acid (36.5\%-38.0\%; J.T. Baker, Holland), sodium acetate trihydrate ( $\geq$ 99.0\%; Sigma-Aldrich, St. Louis, MO, USA), acetic acid (99.5\%-101.5\%; Carlo Erba, Italy), monobasic potassium phosphate ( $\geq 99 \%$ : Sigma-Aldrich, St. Louis, MO USA), and sodium hydroxide ( $\geq 97 \%$; Merck, Germany) were used as received. Caco-2 cells (a human colon carcinoma cell line) were purchased from American Type Culture Collection (ATCC, Gaithersburg, MD, USA). Dulbecco's Modified Eagle's Medium (DMEM), Hank's balanced salt solution (HBSS), and fetal bovine serum (FBS) were all purchased from Biochrom AG (Berlin, Germany), penicillin-streptomycin solution was obtained from Life Technologies, Inc. (Carlsbad, CA, USA), and Thincerts cell culture inserts $(0.4 \mu \mathrm{m})$ were obtained from Greiner BioOne (Frickenhausen, Germany). All other chemicals were of analytical grade.

\section{Tablet Samples}

Commercial tablets containing $1000 \mathrm{mg} \mathrm{MH}$ were obtained from local pharmacies in Turkey and Europe (Switzerland). The generic tablets obtained from Turkey were labeled randomly as A, B, C, D, and E. The reference 
Table 1. Excipient Contents of Generic and Reference Tablets Containing $1000 \mathrm{mg} \mathrm{MH}$

\begin{tabular}{|c|c|c|c|c|c|c|c|}
\hline Function & A & B & C & D & E & TR & ER \\
\hline $\begin{array}{l}\text { Hydrophilic } \\
\text { Polymer }\end{array}$ & $\begin{array}{l}\text { Hydroxy propyl } \\
\text { methyl cellulose }\end{array}$ & & $\begin{array}{l}\text { Hydroxy propyl } \\
\text { methyl cellulose }\end{array}$ & $\begin{array}{l}\text { Hydroxy propyl } \\
\text { methyl cellulose }\end{array}$ & $\begin{array}{l}\text { Hydroxy propyl } \\
\text { methyl cellulose }\end{array}$ & $\begin{array}{l}\text { Hydroxy propyl } \\
\text { methyl cellulose }\end{array}$ & $\begin{array}{l}\text { Hydroxy propyl } \\
\text { methyl cellulose }\end{array}$ \\
\hline Plasticizer & $\begin{array}{l}\text { Polyethylene } \\
\text { glycol } 6000\end{array}$ & & $\begin{array}{l}\text { Polyethylene } \\
\text { glycol } \\
\text { Propylene glycol }\end{array}$ & $\begin{array}{l}\text { Polyethylene } \\
\text { glycol } 4000\end{array}$ & $\begin{array}{l}\text { Polyethylene } \\
\text { glycol } 4000\end{array}$ & $\begin{array}{l}\text { Polyethylene } \\
\text { glycol } 400 \\
\text { Polyethylene } \\
\text { glycol } 8000\end{array}$ & $\begin{array}{l}\text { Polyethylene } \\
\text { glycol } 400 \\
\text { Polyethylene } \\
\text { glycol } 8000\end{array}$ \\
\hline $\begin{array}{c}\text { Binder, } \\
\text { Disintegrant }\end{array}$ & Povidone K25 & Povidone K30 & & Copovidone & Povidone K9 & Povidone K30 & Povidone K30 \\
\hline $\begin{array}{l}\text { Diluent, } \\
\text { Disintegrant }\end{array}$ & & $\begin{array}{l}\text { Microcrystalline } \\
\text { cellulose }\end{array}$ & & $\begin{array}{l}\text { Microcrystalline } \\
\text { cellulose } \\
\text { Sodium starch } \\
\text { glycolate } \\
\text { Lactose } \\
\text { monohydrate }\end{array}$ & & & \\
\hline Lubricant & $\begin{array}{l}\text { Magnesium } \\
\text { stearate }\end{array}$ & $\begin{array}{l}\text { Magnesium } \\
\text { stearate }\end{array}$ & $\begin{array}{l}\text { Magnesium } \\
\text { stearate } \\
\text { Talc }\end{array}$ & $\begin{array}{l}\text { Magnesium } \\
\text { stearate } \\
\text { Colloidal } \\
\text { silicon dioxide }\end{array}$ & $\begin{array}{l}\text { Magnesium } \\
\text { stearate }\end{array}$ & $\begin{array}{l}\text { Magnesium } \\
\text { stearate }\end{array}$ & $\begin{array}{l}\text { Magnesium } \\
\text { stearate }\end{array}$ \\
\hline Colorant & Titanium dioxide & Opadry & Titanium dioxide & Titanium dioxide & Titanium dioxide & & \\
\hline
\end{tabular}

$M H$, metformin hydrochloride; $T R, M H$ reference tablets from Turkish market; $E R, M H$ reference tablets from European market; $A, B, C, D, E: M H$ generic tablets obtained from Turkish market.

tablets obtained from the Turkish and European markets were coded as TR and ER, respectively. The excipient contents of all $\mathrm{MH}$ tablets are presented in Table 1.

\section{Dissolution Studies}

Dissolution studies were performed on the seven IR MH tablets $(1000 \mathrm{mg}$ ) commercially available in the Turkish (one reference and five generic tablets) and European (one reference tablet) drug markets. In accordance with the BCS-based biowaiver criteria, the dissolution studies were performed using a Sotax dissolution testing instrument (Binningerstrassefor, Basel, Switzerland) in USP Apparatus 2 (paddle method) at $50 \mathrm{rpm}$, using 900

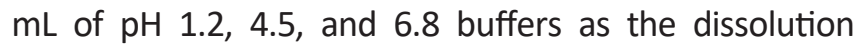
medium. In accordance with the USP monograph, the dissolution test was performed in Apparatus 2 at $75 \mathrm{rpm}$, using $1000 \mathrm{~mL}$ of phosphate buffer (pH 6.8). Six replicates of all dissolution tests were conducted at $37 \pm 0.5^{\circ} \mathrm{C}$. At predetermined time intervals (e.g., 5, 10, 15, 20, and 30 $\mathrm{min})$, a 2-mL sample was withdrawn and then replaced with an equal volume of fresh medium. The withdrawn samples were passed through a $0.45-\mu \mathrm{m}$ membrane filter, and a validated high-performance liquid chromatography (HPLC) method was used to detect the concentration of $\mathrm{MH}$ in the samples.

The dissolution profiles were compared by means of a similarity test. According to the US FDA, "the similarity factor $\left(f_{2}\right)$ is the logarithmic reciprocal square root transformation of the sum of squared error and is Dissolution

Technologies FEBRUARY 2020

www.dissolutiontech.com a measurement of the similarity in the percent (\%) dissolution between the two curves" (8). If more than $85 \%$ of the drug is dissolved within $15 \mathrm{~min}$, the dissolution profiles are considered similar without further mathematical calculation. On the other hand, if less than $85 \%$ is dissolved within $15 \mathrm{~min}$, the $f_{2}$ value should be calculated. All dissolution profiles were compared by means of a model-independent approach $\left(f_{2}\right.$-similarity factor) proposed by Moore and Flanner with the following equation (24):

$$
f_{2}=50 \times \log \left\{\left[1+(1 / n) \sum_{\mathrm{t}=1} n\left(R_{t}-T_{t}\right)^{2}\right]^{-0.5} \times 100\right\}
$$

where $n$ is the number of time points, $R_{t}$ is the dissolved amount of the reference formulation at time $t$, and $T_{t}$ is the dissolved amount of the test formulation at time $t$. Dissolution profiles are considered similar when $f_{2}$ values are greater than 50 .

\section{Permeability Studies}

Human colorectal adenocarcinoma cells that were obtained from the ATCC, USA (Caco-2, passage number 28-32) were seeded at 30,000 cells/well and grown as epithelial monolayers on polycarbonate membrane inserts of 24-well plates for use in determination of the apical to basolateral permeability of $\mathrm{MH}$. Thincerts cell culture inserts $(1.0 \mu \mathrm{m})$ were purchased from Greiner Bio-One, Germany. DMEM, supplemented with $10 \%$ FBS, penicillin (50 units $/ \mathrm{mL})$, and streptomycin $(50 \mu \mathrm{g} /$ $\mathrm{mL}$ ), was used as the growth medium. At 21 days after 
seeding, TEER values of the Caco-2 cells were determined by using a Millicell-ERS voltohmmeter (USA), and the cells with values of $>600 \Omega . \mathrm{cm}^{2}$ were utilized in the transport studies. HBSS (25 mM D-glucose and $10 \mathrm{mM}$ HEPES) was used in all experiments as the transport medium. The solution of $\mathrm{MH}$ in transport medium was freshly prepared at a concentration of $80 \mu \mathrm{M}$. Commercially available tablets containing $1000 \mathrm{mg} \mathrm{MH}$ were powdered separately, and an appropriate amount of the homogeneous powder was dissolved in transport medium to obtain $80 \mu \mathrm{M} \mathrm{MH}$. Drug-containing solutions were added to the apical side $(250 \mu \mathrm{L})$, and drug-free transport medium was added to basolateral side $(750 \mu \mathrm{L})$. Two hours after incubation $\left(37^{\circ} \mathrm{C}\right.$ and $30 \mathrm{rpm}$ ), samples were taken from both the apical and basolateral sides, and then analyzed by using a validated HPLC method. Apical-to-basolateral permeability $\left(P_{a p p}\right)$ values were calculated from the equation: $P_{a p p}=$ rate of transport $\div$ (surface area $\times$ initial concentration).

The results were compared by the Mann-Whitney $\mathrm{U}$ test using IBM SPSS Statistics 23. Differences between the results were considered significant for $p$ values of $<0.05$.

\section{HPLC Analysis}

The HPLC system used for analysis was Shimadzu LC-20 A/Prominence Alliance (Japan). $\mathrm{MH}$ was separated by using a Waters Spherisorb ODS2 $\mathrm{C}_{18}(250 \times 4.6 \mathrm{~mm}, 5 \mu \mathrm{m}$; USA) column. The HPLC system was run at $25^{\circ} \mathrm{C}$ with a mobile phase of phosphate buffer $(\mathrm{pH} \mathrm{3} ; 100 \mathrm{mM})$ and acetonitrile $(30: 70 \mathrm{v} / \mathrm{v})$, a $20-\mu \mathrm{L}$ injection volume, and a flow rate of $1 \mathrm{~mL} / \mathrm{min}$. The diode array detector was fixed at $232 \mathrm{~nm}$, and the retention time of $\mathrm{MH}$ was $2 \mathrm{~min}$. Calibration curves were obtained for all media $(\mathrm{pH} 1.2$, 4.5 , and 6.8 buffers, and transport medium).

\section{RESULTS AND DISCUSSION}

\section{Dissolution Studies}

For an IR drug product of Class 3 compounds, the drug substance should exhibit high solubility (the highest single dose administered as IR formulation is completely dissolved in $250 \mathrm{~mL}$ buffer in the $\mathrm{pH}$ range of 1.2-6.8 at $37 \pm 1^{\circ} \mathrm{C}$ ), with limited absorption (extent of absorption < $85 \%$ ). In addition, very rapid (> 85\% within $15 \mathrm{~min}$ ) in vitro dissolution for the test and reference product within the range of $\mathrm{pH} 1-6.8$ (pH 1.2, 4.5, and 6.8) should be shown. Moreover, excipients that may affect bioavailability should be qualitatively and quantitatively the same, and other excipients should be qualitatively the same and quantitatively very similar $(7,8)$. In dissolution studies, the FDA and EMA differ with respect to the volume of dissolution media (for USP Apparatus 2, FDA: $500 \mathrm{~mL}$ or less [or $900 \mathrm{~mL}$ if appropriately justified]; EMA: $900 \mathrm{~mL}$ or less in buffers of $\mathrm{pH} 1.2,4.5$, and 6.8) and rotation speed (for USP Apparatus 2, FDA: $50 \mathrm{rpm}$ [or at $75 \mathrm{rpm}$ when appropriately justified]; EMA: $50 \mathrm{rpm})(7,8)$.

The dissolution results are presented in Table 2 and the dissolution profiles are displayed in Figure 1. For all $\mathrm{MH}$ tablets (reference and generic tablets), more than $75 \%$ of the labeled amount was dissolved at $\mathrm{pH} 6.8$ phosphate buffer within $30 \mathrm{~min}$, indicating that acceptance criteria stated in the USP monograph was fulfilled. In contrast, the in vitro dissolution criteria of the BCS-based biowaiver was fulfilled only by the generic tablet coded B (Tables 2 and 3). Neither the reference tablets (TR and ER) nor the other generic tablets (except tablet B) were very rapidly dissolved according to the BCS-based biowaiver criteria. Although all generic $\mathrm{MH}$ tablets were rapidly dissolved (more than $85 \%$ dissolved within $30 \mathrm{~min}$ in each buffers), the reference tablets (TR and ER) did not show rapid dissolution in all dissolution media (Table 3 ). The evaluation of dissolution profiles showed that the generic and reference tablets were not similar in the three dissolution media, although the reference tablets from Turkey and Europe were similar (Table 4).

Cheng et al. reported that two marketed IR $500 \mathrm{mg}$ $\mathrm{MH}$ tablets were rapidly dissolved (both formulations released $>89 \% \mathrm{MH}$ in $30 \mathrm{~min}$ ) and showed similar dissolution profiles (USP Apparatus 1 at $100 \mathrm{rpm}$ in 1000 $\mathrm{mL}$ of buffers at three different $\mathrm{pH}$ ) and that the $90 \%$ confidence intervals for the ratio of means ( $A \cup C$ and $C_{\max }$ ) were within the acceptance range of $80 \%-125 \%$ for the log-transformed data, indicating that the two IR products were bioequivalent in 12 healthy Chinese male volunteers (9). In our study, the dissolution profiles of generic tablets were not similar to reference tablets. As suggested by Cheng et al., in vivo absorption of $\mathrm{MH}$ is controlled by membrane permeability rather than dissolution and drug release (9). Therefore, $\mathrm{MH}$ bioavailability will be less dependent on its dissolution behavior. According to the EMA, "in the event that the results of comparative in vitro dissolution of the biobatches do not reflect bioequivalence as demonstrated in vivo the latter prevails" (7).

\section{Permeability Studies}

Caco-2 cells are used widely to determine the permeability of compounds $(25,26)$. Permeability studies across Caco2 provide not only an initial assessment of the intestinal absorption, but also information on the possible effects of drug-excipient interactions on the absorption.

It was demonstrated that $\mathrm{MH}$ has concentration- and $\mathrm{pH}$ dependent, non-saturable, non-polar and linear (for $>1 \mathrm{~h}$ ) transfer across Caco- 2 cells, with a $\mathrm{P}_{\text {app }}$ value of $5.5 \times 10^{-6}$ 
Table 2. Dissolution Results for Generic and Reference Tablets Containing $1000 \mathrm{mg} \mathrm{MH} \mathrm{(} \mathrm{m}=6)$

\begin{tabular}{|c|c|c|c|c|c|c|c|c|}
\hline \multirow{3}{*}{ Tablets } & \multicolumn{6}{|c|}{ BCS-Based Biowaiver (\% dissolved) } & \multirow{2}{*}{\multicolumn{2}{|c|}{$\begin{array}{l}\text { USP-Monograph (\% dissolved) } \\
\text { pH } 6.8 \text { phosphate buffer** }\end{array}$}} \\
\hline & \multicolumn{2}{|c|}{ pH 1.2 buffer* } & \multicolumn{2}{|c|}{ pH 4.5 buffer* } & \multicolumn{2}{|c|}{ pH 6.8 buffer* } & & \\
\hline & $15 \mathrm{~min}$ & $30 \mathrm{~min}$ & $15 \mathrm{~min}$ & $30 \mathrm{~min}$ & $15 \mathrm{~min}$ & $30 \mathrm{~min}$ & $15 \mathrm{~min}$ & $30 \mathrm{~min}$ \\
\hline A & $63.58 \pm 5.37$ & $100.5 \pm 5.98$ & $66.28 \pm 6.42$ & $92.62 \pm 2.55$ & $89.40 \pm 7.59$ & $100.95 \pm 1.69$ & $91.71 \pm 1.12$ & $96.66 \pm 1.64$ \\
\hline B & $91.12 \pm 4.14$ & $105.12 \pm 6.21$ & $85.00 \pm 4.30$ & $95.82 \pm 2.78$ & $92.62 \pm 4.11$ & $100.38 \pm 1.56$ & $98.69 \pm 1.08$ & $97.06 \pm 2.27$ \\
\hline C & $63.04 \pm 9.14$ & $91.16 \pm 5.10$ & $74.32 \pm 7.39$ & $96.74 \pm 2.10$ & $76.38 \pm 3.75$ & $98.50 \pm 1.08$ & $94.00 \pm 2.82$ & $98.04 \pm 1.46$ \\
\hline D & $79.38 \pm 2.88$ & $96.91 \pm 3.05$ & $69.19 \pm 5.75$ & $94.46 \pm 2.39$ & $70.99 \pm 7.57$ & $95.92 \pm 2.00$ & $90.01 \pm 1.92$ & $96.81 \pm 0.27$ \\
\hline $\mathbf{E}$ & $55.59 \pm 4.76$ & $88.73 \pm 2.74$ & $66.65 \pm 5.54$ & $96.06 \pm 1.15$ & $56.83 \pm 5.69$ & $89.15 \pm 4.98$ & $80.80 \pm 9.73$ & $98.49 \pm 0.86$ \\
\hline TR & $31.10 \pm 2.18$ & $45.63 \pm 3.06$ & $38.41 \pm 4.01$ & $63.68 \pm 4.80$ & $37.95 \pm 3.18$ & $61.57 \pm 4.64$ & $59.10 \pm 6.36$ & $87.65 \pm 7.26$ \\
\hline ER & $22.03 \pm 2.58$ & $30.46 \pm 5.03$ & $34.05 \pm 2.13$ & $50.50 \pm 3.17$ & $45.09 \pm 3.48$ & $71.48 \pm 5.58$ & $64.36 \pm 6.81$ & $93.38 \pm 7.00$ \\
\hline
\end{tabular}

Values are expressed as mean $\pm S D$. *Apparatus 2 (paddle), $50 \mathrm{rpm}, 900 \mathrm{~mL}$; ${ }^{* *}$ Apparatus 2 (paddle), $75 \mathrm{rpm}, 1000 \mathrm{~mL}$. MH, metformin hydrochloride; TR, $\mathrm{MH}$ reference tablets from Turkish market; $E R, M H$ reference tablets from European market; $A, B, C, D, E$ : MH generic tablets obtained from Turkish market.
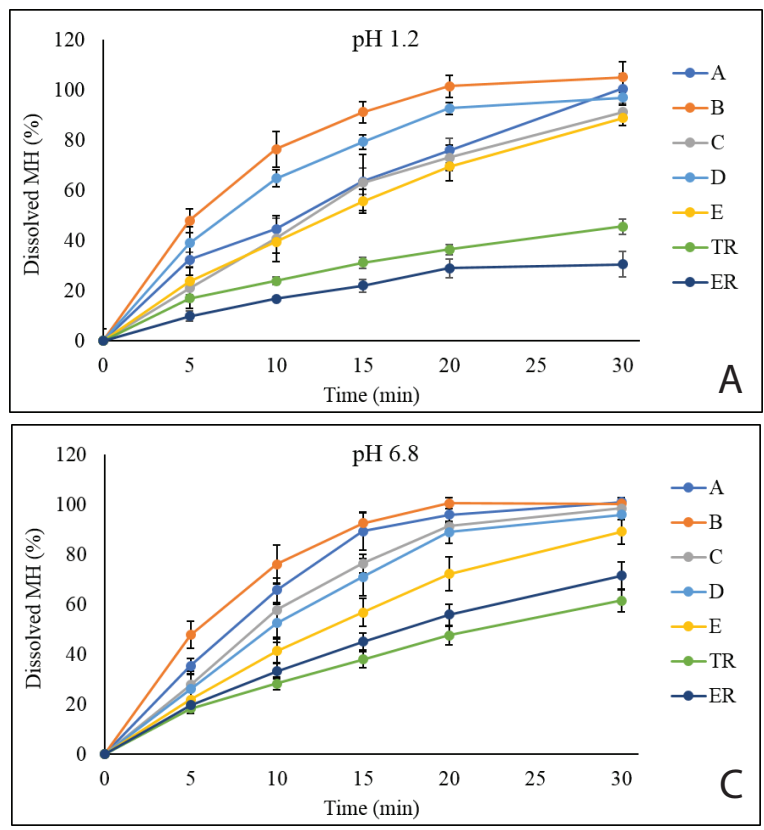
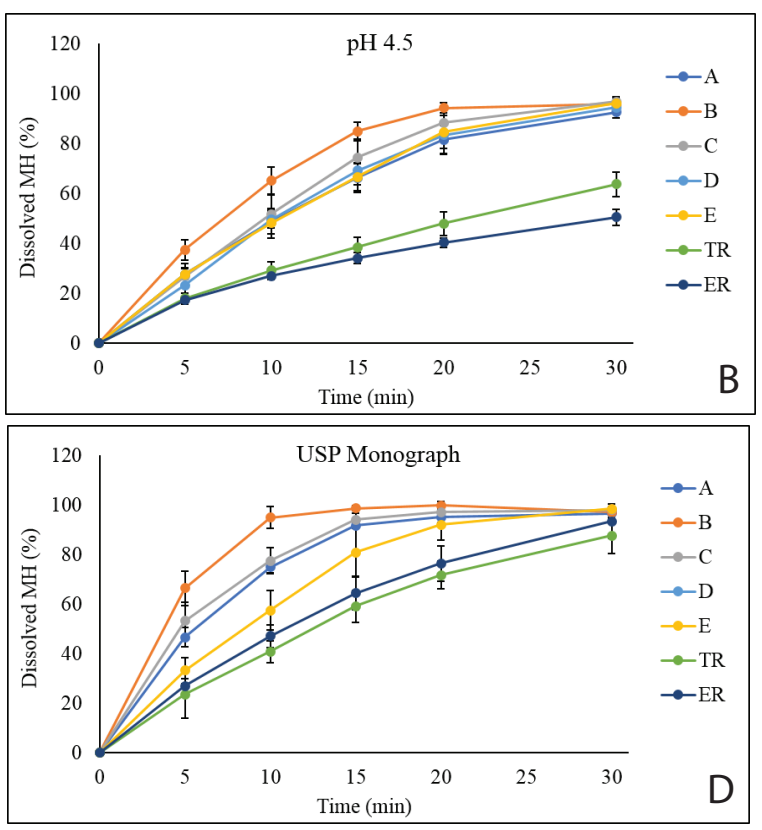

Figure 1. Dissolution profiles (mean $\pm S D ; n=6$ ) of commercially available tablets containing $1000 \mathrm{mg} \mathrm{MH} \mathrm{in} \mathrm{pH} 1.2(\mathrm{~A}), \mathrm{pH} 4.5(\mathrm{~B}), \mathrm{pH} 6.8(\mathrm{C})$ buffer mediums, and USP monograph conditions (D). $M H$, metformin hydrochloride; TR, $M H$ reference tablets from Turkish market; ER, $M H$ reference tablets from European market; $A, B, C, D, E: M H$ generic tablets obtained from Turkish market.

Table 3. Dissolution Properties of Tablets Containing $1000 \mathrm{mg} \mathrm{MH}$

\begin{tabular}{|c|c|c|c|c|c|c|c|}
\hline \multirow[b]{3}{*}{ Tablets } & \multicolumn{6}{|c|}{ BCS-Based Biowaiver } & \multirow{3}{*}{$\begin{array}{c}\text { USP-Monograph } \\
\text { pH } 6.8 \text { phosphate buffer } \\
\text { Meets Criteria*** }\end{array}$} \\
\hline & \multicolumn{2}{|c|}{ pH 1.2 buffer } & \multicolumn{2}{|c|}{ pH 4.5 buffer } & \multicolumn{2}{|c|}{ pH 6.8 buffer } & \\
\hline & $\begin{array}{l}\text { Very Rapidly } \\
\text { Dissolving* }\end{array}$ & $\begin{array}{l}\text { Rapidly } \\
\text { Dissolving** }\end{array}$ & $\begin{array}{l}\text { Very Rapidly } \\
\text { Dissolving }\end{array}$ & $\begin{array}{l}\text { Rapidly } \\
\text { Dissolving }\end{array}$ & $\begin{array}{l}\text { Very Rapidly } \\
\text { Dissolving }\end{array}$ & $\begin{array}{l}\text { Rapidly } \\
\text { Dissolving }\end{array}$ & \\
\hline A & - & + & - & + & + & + & + \\
\hline B & + & + & + & + & + & + & + \\
\hline C & - & + & - & + & - & + & + \\
\hline D & - & + & - & + & - & + & + \\
\hline E & - & + & - & + & - & + & + \\
\hline TR & - & - & - & - & - & - & + \\
\hline ER & - & - & - & - & - & - & + \\
\hline
\end{tabular}

${ }^{*}$ More than $85 \%$ of the labeled amount of drug dissolves within $15 \mathrm{~min} ;{ }^{* *}$ More than $85 \%$ of the labeled amount of drug dissolves within 30 min; ${ }^{* * *}$ More than $75 \%$ of the labeled amount of drug dissolves within 30 min; + indicates that tablets meet the criteria specified in the column; - indicates that tablets do not meet the criteria specified in the column. MH, metformin hydrochloride; TR, MH reference tablets from Turkish market; ER, MH reference tablets from European market; $A, B, C, D, E: M H$ generic tablets obtained from Turkish market. 
Table 4. Similarity $\left(f_{2}\right)$ Values of Tablets Containing $1000 \mathrm{mg} \mathrm{MH}$

\begin{tabular}{|c|c|c|c|c|c|}
\hline & & \multicolumn{4}{|c|}{$f_{2}$ values } \\
\hline Reference & Generic & pH 1.2 & pH 4.5 & pH 6.8 & USP \\
\hline TR & A & 22.49 & 29.75 & 19.58 & 29.21 \\
\hline TR & B & 12.99 & 21.31 & 16.99 & 21.02 \\
\hline TR & C & 25.57 & 26.67 & 23.54 & 26.91 \\
\hline TR & D & 17.15 & 28.56 & 25.84 & 30.56 \\
\hline TR & E & 27.84 & 28.40 & 35.43 & 39.00 \\
\hline ER & A & 17.34 & 24.79 & 23.48 & 33.54 \\
\hline ER & B & 9.62 & 18.13 & 20.28 & 23.79 \\
\hline ER & C & 19.88 & 22.29 & 28.43 & 30.75 \\
\hline ER & D & 13.13 & 23.82 & 31.38 & 35.23 \\
\hline ER & E & 21.54 & 23.65 & 44.97 & 46.47 \\
\hline ER & TR & $\mathbf{5 0 . 6 1}$ & $\mathbf{5 7 . 5 1}$ & $\mathbf{5 7 . 0 8}$ & $\mathbf{6 3 . 9 4}$ \\
\hline
\end{tabular}

$\mathrm{MH}$, metformin hydrochloride; USP, United States Pharmacopeia; TR, MH reference tablets from Turkish market; $E R, M H$ reference tablets from

European market; $A, B, C, D, E: M H$ generic tablets obtained from Turkish market.

$\mathrm{cm} / \mathrm{s}$ at pH 7.4 (27). In another study, $P_{\text {app }}$ and $P_{\text {app, }}$, total $\left(P_{a p p}+P_{a p p}\right.$, tissue, which is the value of time-dependent accumulation in the tissue) values of $\mathrm{MH}$ were reported as $(6.67 \pm 0.54) \times 10^{-6} \mathrm{~cm} / \mathrm{s}$ and $(7.68 \pm 1.62) \times 10^{-6} \mathrm{~cm} / \mathrm{s}$, respectively, for human small intestinal and colonic mucosa by using the Ussing chamber technique (28). In addition, the permeability values of $\mathrm{MH}$ were reported by using the everted gut sac $\left(7.37 \times 10^{-7} \mathrm{~cm} / \mathrm{s}\right)$ and Sartorius SM 16750 apparatus $\left(6.13 \times 10^{-7} \mathrm{~cm} / \mathrm{s}\right)(29)$. In contrast, higher permeability values were determined for $\mathrm{MH}$ across the duodenum $\left(4.5 \times 10^{-5} \mathrm{~cm} / \mathrm{s}\right)$, jejunum $(3.3 \times$ $\left.10^{-5} \mathrm{~cm} / \mathrm{s}\right)$, and ileum $\left(3.0 \times 10^{-5} \mathrm{~cm} / \mathrm{s}\right)$ of rats $(30)$. Our permeability value determined for raw $\mathrm{MH}\left(4.14 \times 10^{-5}\right.$ $\mathrm{cm} / \mathrm{s}$ ) was within the range of $P_{a p p}$ values reported in the literature (Fig. 2). In vitro permeability across Caco-2 cells can be used to predict in vivo (small intestinal) absorption in humans. According to the Caco- 2 permeabilities, the compounds are classified as poorly $\left(0 \%-20 \% ; \mathrm{P}_{\mathrm{app}}<1 \times\right.$ $\left.10^{-6} \mathrm{~cm} / \mathrm{s}\right)$, moderately (20\%-70\%; $P_{\text {app }}$ between (1-10) $\times$ $\left.10^{-6} \mathrm{~cm} / \mathrm{s}\right)$, and well $\left(70 \%-100 \% ; P_{a p p}>10 \times 10^{-6} \mathrm{~cm} / \mathrm{s}\right)$ absorbed compounds (31).

There was no statistically significant difference between the $\mathrm{MH}$ permeability values determined for all reference and generic tablet formulations and the raw $\mathrm{MH}$ permeability value $(p>0.05)$, indicating that the excipients used in the tablets did not significantly change the $\mathrm{MH}$ permeability. However, a significant difference in permeability was observed for the two reference tablets. The tablet from Switzerland (ER) displayed higher MH permeability than the tablet from Turkey (TR) $(p<$ 0.05 ) (Fig. 2). This may be related to the differences in

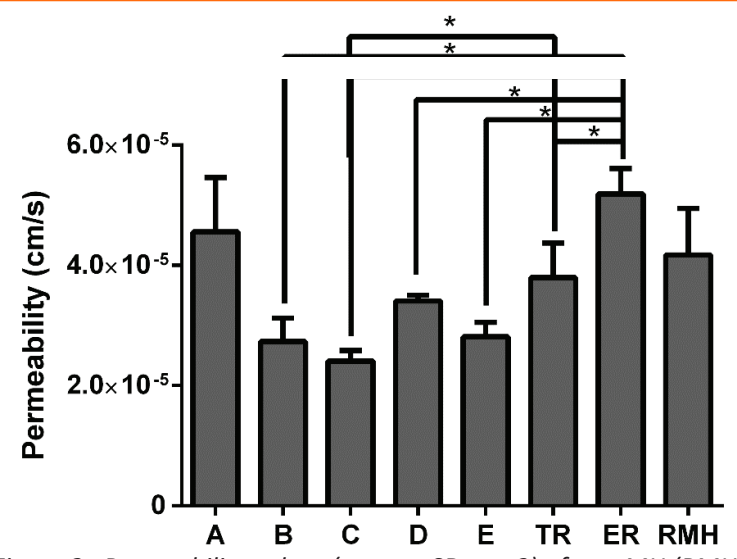

Figure 2. Permeability values (mean $\pm S D ; n=3$ ) of raw $M H(R M H)$ and commercial tablets containing $1000 \mathrm{mg} \mathrm{MH}$. *indicates statistical significance $p<0.05 . \mathrm{MH}$, metformin hydrochloride; TR, $M H$ reference tablets from Turkish market; $E R, M H$ reference tablets from European market; $A, B, C, D, E: M H$ generic tablets obtained from Turkish market. the manufacturing processes, as both reference tablets contain the same excipients (Table 1).

Based on these results, the reference tablet chosen for the comparison of $\mathrm{MH}$ permeability between the reference and generic tablets is important. When the ER tablet was selected as the reference, the permeability of generic tablets $B, C, D$, and $E$ was significantly lower $(p<0.05)$. However, when compared to the TR tablet, a significant decrease in $\mathrm{MH}$ permeability was observed for generic tablet $\mathrm{C}$ only $(p<0.05)$. Only generic tablet $\mathrm{A}$ had permeability similar to both reference tablets (Fig. 2). As shown in Table 1, tablets do not contain any excipients that might affect permeability, and no significant differences between raw $\mathrm{MH}$ and formulations were observed. In contrast, generic tablets $B, D$, and $E$ displayed significantly lower $\mathrm{MH}$ permeability than the ER tablet. Although formulations of TR and ER tablets were qualitatively the same, and all generic formulations were similar to them, the difference may have been caused by active ingredient characteristics and production-related differences, given the high $\mathrm{MH}$ content.

\section{HPLC Analysis}

The results of HPLC analysis revealed that the method was simple and sufficiently sensitive to perform qualitative and quantitative analysis of $\mathrm{MH}$ from the dissolution and permeability samples and may be used for quality control studies of tablets containing $1000 \mathrm{mg} \mathrm{MH}$. All calibration curves had determination coefficient $\left(R^{2}\right)$ values $>0.999$. Further, there was no interfering peak at the retention time of $\mathrm{MH}$, indicating that the HPLC method used for analysis was selective. 


\section{CONCLUSIONS}

$\mathrm{MH}$, a BCS Class 3 drug with high solubility and low permeability, is a commonly used antidiabetic drug for the treatment of type II diabetes. We evaluated the dissolution and permeability properties of commercially available IR generic drugs obtained from the Turkish market and reference $\mathrm{MH}$ tablets obtained from Turkish and European markets. Except for generic tablet B, neither the generic nor the reference $\mathrm{MH}$ tablets fulfilled the very rapid dissolution criteria (> 85\% in $15 \mathrm{~min}$ ). The comparison of the dissolution profiles revealed that although the reference tablets obtained from Turkish and European (Swiss) markets were similar $\left(f_{2}>50\right)$, none of the generic tablets were similar to either of the reference tablets. $\mathrm{MH}$ is a low permeability compound; therefore, the effect of excipients on the permeability of $\mathrm{MH}$ can alter bioavailability. Collectively, all results obtained from this study indicate that IR MH tablets do not meet the criteria for very rapid dissolution, as recommended by the guidelines for the BCS-based biowaiver for Class 3 compounds. Therefore, in vivo studies should be performed to demonstrate the bioequivalence of generic and reference tablet containing $\mathrm{MH}$.

\section{ACKNOWLEDGMENTS}

Nihan Izat is supported by The Scientific and Technological Research Council of Turkey (2211-A grant). The authors disclosed no other support related to this work.

\section{CONFLICT OF INTEREST}

The authors disclosed no conflicts of interest related to this article.

\section{REFERENCES}

1. Cetin, M.; Sahin, S. Microparticulate and nanoparticulate drug delivery systems for metformin hydrochloride. Drug Deliv. 2015, 23, 2796-2805. DOI: 10.3109/10717544.2015.1089957.

2. Inzucchi, S. E.; Lipska, K. J.; Mayo, H.; Bailey, C. J.; McGuire, D. K. Metformin in patients with type 2 diabetes and kidney disease: a systematic review. JAMA. 2014, 312, 2668-2675. DOI: 10.1001/ jama.2014.15298.

3. An, H.; He, L. Current understanding of metformin effect on the control of hyperglycemia in diabetes. J. Endocrinol. 2016, 228 (3), 97-106. DOI: 10.1530/JOE-15-0447.

4. Inzucchi, S. E.; Bergenstal, R. M.; Buse, J. B.; Diamant, M.; Ferrannini, E.; Nauck, M.; Peters, A. L.; Tsapas, A.; Wender, R.; Matthews, D. R. Management of hyperglycaemia in type 2 diabetes: a patient-centered approach. Position statement of the American Diabetes Association (ADA) and the European Association for the Study of Diabetes (EASD). Diabetologia. 2012, 55, 1577-1596. DOI: 10.1007/s00125-012-2534-0.

5. Orange Book: Approved Drug Products with Therapeutic
Equivalence Evaluations. U.S. Food and Drug Administration website.https://www.accessdata.fda.gov/scripts/cder/ob/ search_product.cfm. Accessed Dec 4, 2018.

6. WHO Expert Committee on Specifications for Pharmaceutical Preparations. Multisource (Generic) Pharmaceutical Products: Guidelines on Registration Requirements to Establish Interchangeability; WHO Technical Report Series, No. 992 Annex 7; World Health Organiztion: Geneva, Switzerland, 2015. DOI: 10.1002/jps.2600620248.

7. Guideline on the Investigation of Bioequivalence; CPMP/EWP/ QWP/1401/98 Rev. 1;. Committee for Medicinal Products for Human Use (CHMP), European Medicines Agency: London, 2010.

8. Waiver of In Vivo Bioavailability and Bioequivalence Studies for Immediate-Release Solid Oral Dosage Forms Based on a Biopharmaceutics Classification System; Guidance for Industry; U.S. Department of Health and Human Services, Food and Drug Administration, Center for Drug Evaluation and Research (CDER), U.S. Government Printing Office: Washington, DC, 2017. DOI: 10.1201/9780824741969.axh.

9. Cheng, C. L.; Yu, L. X.; Lee, H. L.; Yang, C. Y.; Lue, C. S.; Chou, C. $\mathrm{H}$. Biowaiver extension potential to BCS Class III high solubilitylow permeability drugs: bridging evidence for metformin immediate-release tablet. Eur. J. Pharm. Sci. 2004, 22, 297-304. DOI: 10.1016/j.ejps.2004.03.016.

10. Crison, J. R.; Timmins, P.; Keung, A.; Upreti, V. V.; Boulton, D. W.; Scheer, B. J. Biowaiver approach for biopharmaceutics classification system class 3 compound metformin hydrochloride using in silico modeling. J. Pharm. Sci. 2012, 101, 1773-1782. DOI: 10.1002/jps.23063.

11. O'Hara, T.; Dunne, A.; Butler, J.; Devane, J. A review of methods used to compare dissolution profile data. Pharm. Sci. Technol. Today. 1998, 1, 214-223. DOI:10.1016/S1461-5347(98)00053-4.

12. Ozturk, N.; Kaynak, M. S.; Sahin, S. Comparison of dissolution profiles of commercially available lamivudine tablets. Dissolution Technol. 2015, 22, 38-43. DOI: 10.14227/DT220415P38.

13. Rege, B. D.; Yu, L. X.; Hussain, A. S.; Polli, J. E. Effect of common excipients on Caco-2 transport of low-permeability drugs. J. Pharm. Sci. 2001, 90, 1776-1786. DOI: 10.1002/jps.1127.

14. Van der Lubben, I.; Van Opdorp, F.; Hengeveld, M.; Onderwater, J.; Koerten, H.; Verhoef, J; Borchard, G.; Junginger, H. E. Transport of chitosan microparticles for mucosal vaccine delivery in a human intestinal M-cell model. J. Drug Target. 2002, 10, 449456. DOI: 10.1080/1061186021000038319.

15. Kernéis, S.; Bogdanova, A.; Kraehenbuhl, J-P.; Pringault, E. Conversion by Peyer's patch lymphocytes of human enterocytes into M cells that transport bacteria. Science. 1997, 277, 949-952. DOI: 10.1126/science.277.5328.949.

16. Gullberg, E.; Leonard, M.; Karlsson, J.; Hopkins, A. M.; Brayden, D.; Baird, A. W; Artursson, P. Expression of specific markers and particle transport in a new human intestinal M-cell model. Biochem. Biophys. Res. Commun. 2000, 279, 808-813. DOI: 
10.1006/bbrc.2000.4038.

17. Wikman-Larhed, A.; Artursson, P. Co-cultures of human intestinal goblet (HT29-H) and absorptive (Caco-2) cells for studies of drug and peptide absorption. Eur. J. Pharm. Sci. 1995, 3, 171-183. DOI: 10.1016/0928-0987(95)00007-Z.

18. van Breemen, R. B.; Li, Y. Caco-2 cell permeability assays to measure drug absorption. Expert Opin. Drug Metab. Toxicol. 2005, 1, 175-185. DOI: 10.1517/17425255.1.2.175.

19. Chandler, C. E.; Zaccaro, L. M.; Moberly, J. B. Transepithelial transport of cholyltaurine by Caco-2 cell monolayers is sodium dependent. Am. J. Physiol. Gastrointest. Liver Physiol. 1993, 264, 1118-1125. DOI: 10.1152/ajpgi.1993.264.6.G1118.

20. Hidalgo, I. J.; Hillgren, K. M.; Grass, G. M.; Borchardt, R. T. Characterization of the unstirred water layer in Caco-2 cell monolayers using a novel diffusion apparatus. Pharm. Res. 1991, 8, 222-227. DOI: 10.1023/A:1015848205447.

21. Sun, H.; Chow, E. C. Y.; Liu, S.; Du, Y.; Pang, K. S. The Caco-2 cell monolayer: usefulness and limitations. Expert Opin. Drug Metab. Toxicol. 2008, 4, 395-411. DOI: 10.1517/17425255.4.4.395.

22. ICH Guideline M9 on Biopharmaceutics Classification System Based Biowaivers; EMA/CHMP/ICH/493213/2018; Committee for Medicinal Products for Human Use (CHMP), European Medicines Agency: London, 2018.

23. van Oudtshoorn, J. E.; García-Arieta, A.; Santos, G. M. L.; Crane, C.; Rodrigues, C.; Simon, C.; Kim, J. M.; Park, S. A.; Okada, Y.; Kuribayashi, R.; Pfäffli, C.; Nolting, A.; Lojero, I. O. C.; Martínez, Z. R.; Hung, W. Y.; Braddy, A. C.; Leal, N. A.; Triana, D. G.; Clarke, M.; Bachmann, P. A survey of the regulatory requirements for BCSbased biowaivers for solid oral dosage forms by participating regulators and organisations of the international generic drug regulators programme. J. Pharm. Pharm. Sci. 2018, 21, 27-37. DOI: $10.18433 / J 3 X 93 K$.
24. Moore, J. W.; Flanner, H. H. Mathematical comparison of curves with an emphasis on in vitro dissolution profiles. Pharm. Tech. 1996, 20, 64-74.

25. Shah, P.; Jogani, V.; Bagchi, T.; Misra, A. Role of Caco-2 cell monolayers in prediction of intestinal drug absorption. Biotechnol. Prog. 2006, 22, 186-198. DOI: 10.1021/bp050208u.

26. Dimitrijevic, D.; Shaw, A. J.; Florence, A. T. Effects of some non-ionic surfactants on transepithelial permeability in Caco-2 cells. J. Pharm. Pharmacol. 2000, 52, 157-162. DOI: 10.1211/0022357001773805.

27. Nicklin, P.; Keates, A. C.; Page, T.; Bailey, C. J. Transfer of metformin across monolayers of human intestinal Caco-2 cells and across rat intestine. Int. J. Pharm. 1996, 128, 155-162. DOI 10.1016/0378-5173(95)04259-8.

28. Rozehnal, V.; Nakai, D.; Hoepner, U.; Fischer, T.; Kamiyama, E.; Takahashi, M.; Yasuda, S.; Mueller, J. Human small intestinal and colonic tissue mounted in the Ussing chamber as a tool for characterizing the intestinal absorption of drugs. Eur. J. Pharm. Sci. 2012, 46, 367-373. DOI: 10.1016/j.ejps.2012.02.025.

29. Lassoued, M. A.; Khemiss, F.; Sfar, S. Comparative study of two in vitro methods for assessing drug absorption: Sartorius SM 16750 apparatus versus everted gut sac. J. Pharm. Sci. 2011, 14, 117-127. DOI: 10.18433/J3GC7R.

30. Song, N. N.; Li, Q. S.; Liu, C. X. Intestinal permeability of metformin using single-pass intestinal perfusion in rats. World J. Gastroenterol. 2006, 12, 4064-4070. DOI: 10.3748/wjg.v12. i25.4064.

31. Yee, S. In vitro permeability across Caco-2 cells (colonic) can predict in vivo (small intestinal) absorption in man-fact or myth. Pharm. Res. 1997, 14, 763-766. DOI: 10.1023/a:1012102522787. 